\section{Selcuk Journal of Agriculture and Food Sciences}

http://sjafs.selcuk.edu.tr/sjafs/index

Research Article
SJAFS

(2019) 33 (3), 183-189

e-ISSN: 2458-8377

DOI:10.15316/SJAFS.2019.173

\title{
Machinery Levels of Black Carrot-Producing Agricultural Enterprises in Ereğli and Karapınar Towns of Konya Province**
}

\author{
Mahmut YILMAZ ${ }^{1}$, Haydar HACISEFEROĞULLARI ${ }^{1, *}$ \\ ${ }^{1}$ Selçuk University, Faculty of Agriculture, Department of Agricultural Machineries and Technologies Engineering, \\ Konya, Turkey

\begin{tabular}{l}
\hline ARTICLE INFO \\
\hline Article history: \\
Received date: 15.07 .2019 \\
Accepted date: 29.07 .2019 \\
\hline Edited by: \\
Osman ÖZBEK; Selçuk University, \\
Turkey \\
Reviewed by: \\
Hüseyin Kürşat ÇELIK; Akdeniz Univer- \\
sity, Turkey \\
Hasan ARISOY; Selcuk University, \\
Turkey \\
\hline
\end{tabular}

\begin{abstract}
The primary objective of the present study was to generate a database for mechanization levels of black carrot-producing agricultural enterprises in Konya region. Sample villages were selected purposefully, and 37 enterprises were visited to apply face-to-face questionnaires. Present findings revealed that land size per enterprise was $1124.6 \mathrm{da}$, average number of plots was 10.2 , total number of plots was 379 and average plot size was 78.8 da. About $62.69 \%$ of total cultivated lands was used for black carrot production and it was respectively followed by irrigated wheat farming (15.39\%), tomato cultivation $(7.09 \%)$ and irrigated barley farming $(6.61 \%)$. With regard to mechanization level of the present enterprises, number of tractors per enterprise was 2.81, average tractor power was $68.65 \mathrm{~kW}$, number of tools and machines per tractor was 6.52 , mass of tool-machine per tractor was 9.45 tons, average engine power per unit area was $1.72 \mathrm{~kW} \mathrm{ha}^{-1}$, number of tractors per 1000 ha land area was 24.99 and cultivated land per tractor was calculated as 40.01 ha.
\end{abstract}

Keywords:

Agricultural Machinery

Agricultural Mechanization

Ereğli town

Karapınar town

Mechanization Level

Tractor

\section{Introduction}

Black carrot is largely consumed in Turkey. Black carrot is not consumed much as fresh vegetable, it is mostly used as fermented juice. Carrot is a root-crop. Central Anatolia region and especially Konya province is the greatest carrot producer of Turkey. Yellow carrot is produced in Kaşınhanı town of Konya and black carrot is commonly produced in Ereğli and Karapınar towns of Konya. Reliable data are not available for the carrot production of the region.

It was estimated that companies had growers performed black carrot cultivation for concentrate juice production over 40 thousand da land area of the region in 2018 and purchased about 160 thousands of black carrot (130 thousand tons for concentrate and 30 thousand tons for turnip) and such a quantity corresponded about 40 thousand decares.

\footnotetext{
* Corresponding author email: hhsefer@selcuk.edu.tr

** This study was produced from Master's thesis of Mahmut YILMAZ
}

Black carrot contains $26.40 \mathrm{mg}(100 \mathrm{ml})^{-1}$ ascorbic acid (Kirca 2004). Turnip juice produced from black carrot is a fermented product and has an appetizing characteristic (Canbaş and Deryaoğlu 1993). Turnip juice also contains lactic acid. Lactic acid gives a sour taste to turnip juice, facilitates mineral use of the body and regulates $\mathrm{pH}$ of digestive system. It is a peptic and refreshing product (Miişoğlu 2004). Black carrot has a quite high antioxidant activity and it is a good source of anthocyanin pigment. It is a remarkable product with a high anthocyanin content $\left(1750 \mathrm{mg} \mathrm{kg}^{-1}\right)$ and special quality parameters (Kurca et al 2006). Anthocyanins are the most natural food dies providing shiny red color to foodstuffs and commonly used as an alternative to synthetic colorants (Bridle and Timberlake 1997, Giusti and Wrolstad 2003). Black carrot concentrate is also used as a natural fabric dye.

Agricultural structures of the regions are generally assessed through number of agricultural enterprises, land sizes of these enterprises, number of plots of each enterprise, credit supply, household share, number, age, gender and education of workers of enterprises. Agricultural mechanization levels should also be put forth in such assessments. 
In previous studies, mechanization levels of carrot (yellow) producing enterprises of Konya province (Yokuş et al 2015), Çumra town of Konya province (Keleş and Hacıseferoğulları 2016), enterprises of Şanlıurfa-Harran plain (Bozkurt and Aybek 2016), enterprises of Muş plain (Akar and Çelik 2017), Kirklareli province (Kayhan et al 2017), Malatya province (Aslantürk and Altuntaş 2018), sunflowerproducing enterprises of Çorum province (Altuntaş and Bal 2018) and Karaman province (Kirpitçi et al 2018) were investigated.

Among the agricultural inputs of black carrot production, mechanization investments constitute a significant place. Therefore, structure and mechanization characteristics of the producer enterprises should be well analyzed for planned and properly mechanization investment in carrot production. There aren't any studies in literature about mechanization levels of black carrot-producing enterprises. Thus, in this study, tractor and agricultural machinery inventories and agricultural mechanization levels of agricultural enterprises were determined.

\section{Materials and Methods}

Four districts (villages) of Ereğli and Karapınar towns of Konya province were selected as the research sites of the present study. Black carrot is produced in these villages (Kuzukuyu and Beyören districts of Ereğli town and Akören and Oymalı districts of Karapınar town. Black carrot-producing agricultural enterprises of these districts constituted the research population. About $90 \%$ of regional production come from these four villages. Therefore, these villages (Kuzukuyu, Beyören, Oymalı and Akören) were selected purposefully. Questionnaire forms were applied to enterprise managers through face-to-face meetings in November and December of 2018.

Interviews were made with the local authority (mukhtar) of these villages and 2018 Farmer's Registration System records were assessed and ultimately 75 black carrot-producing agricultural enterprises were determined. While selecting these enterprises, enterprises with small land sizes and different enterprises of the same family were not taken into consideration. Full-count method was applied to these enterprises. However, some enterprises rejected to participate into the survey and some were not able to be found in their places. Therefore, questionnaires were applied to 37 black carrot-producing agricultural enterprises. Resultant data were also supported with observation technique. Total sowing area of black carrot-producing agricultural enterprises of the region is around 40000 da. Sowing area of questionnaire-applied 37 enterprises is 26090 da corresponding to $65 \%$ of total sowing area of the region.
Annual total fuel consumptions were used for better assessment of annual tractor operational durations of the enterprises. Engine power and specific fuel consumption of the enterprise tractors were also taken into consideration and the following equations were used in relevant calculations (Işı1k and Atun 1998):

$\mathrm{AOD}=\mathrm{AFC} /(\mathrm{SFC} \times \mathrm{LR} \times \mathrm{Pm})$

AOD :Annual operational duration $\left(\mathrm{h}_{\text {year }}{ }^{-1}\right)$,

AFC : Annual total fuel consumption $\left(\mathrm{L} \mathrm{year}^{-1}\right)$,

SFC : :Specific fuel consumption $\left(\mathrm{LkWh}^{-1}\right)$,

LR :Tractor loading rate, taken as 0.40 ,

$\mathrm{Pm}$ : Tractor engine power $(\mathrm{kW})$.

SPSS software was used for statistical analyses of survey data. Frequency, percentiles and mean values were used in data analysis.

\section{Results and Discussion}

\section{General characteristics}

Of the participant enterprises, $43.2 \%$ were doing this business for $\geq 21$ years, $21.6 \%$ for $16-20$ years, $16.2 \%$ for $6-10$ years, $16.2 \%$ for $11-15$ years and $2.7 \%$ for 1-5 years. In general, present enterprises were quite experienced in black carrot production.

Ages of enterprise owners varied between $25-61$ years with an average age of 43.6 year. As compared to average farmer's age of International Labor Organization (ILO) (58 years), average age of enterprise owners was low (Evcim et al 2015).

Of the participant enterprise owners, $51.4 \%$ had primary school education, $10.8 \%$ had secondary school education, $29.7 \%$ had high school education and $8.1 \%$ had university education. Survey results revealed that households contributed to agricultural productions in $91.9 \%$ of the enterprises and did not have any contributions in $8.1 \%$ of the enterprises.

Total sowing area of the present enterprises was 41 610 da corresponding to a land size of 1124.6 da per enterprise. Total sowing area of the enterprises varied between $40-500$ da and land size was mostly $(8.1 \%)$ 200 da. Number of plots varied between 1- 32 with an average value of 10.2. Total number of plots was 379 and average plot size was $78.8 \mathrm{da}$.

Plant production status of black carrot-producing enterprises is provided in Table 1. Black carrot production was performed on $62.69 \%$ of total sowing area. It was respectively followed by irrigated wheat farming $(15.39 \%)$, tomato cultivation $(7.09 \%)$ and irrigated barley farming $(6.61 \%)$. Apart from these products, maize $(2.64 \%)$, alfalfa $(2.27 \%)$, potato $(1.20 \%)$, silage maize $(1.17 \%)$ and sugar beet $(0.73 \%)$ were cultivated by the present enterprises. 
Table 1

Plant production over the agricultural fields

\begin{tabular}{lcccc}
\hline Type of crop & Sowing area $(\mathrm{da})$ & Yield $\left(\mathrm{kg} \mathrm{da}^{-1}\right)$ & Total number of Enterprises & Frequency (\%) \\
\hline Irrigated farming & & & & \\
Black carrot & 26090 & 4028.4 & 37 & 62.69 \\
Wheat & 6405 & 788.2 & 20 & 15.39 \\
Barley & 2750 & 599 & 12 & 6.61 \\
Silage maize & 486 & 5714 & 7 & 1.17 \\
Alfalfa & 944 & 1800 & 13 & 2.27 \\
Kernel maize & 1100 & 1500 & 2 & 2.64 \\
Tomato & 2950 & 10899 & 9 & 7.09 \\
Potato & 500 & 4500 & 1 & 0.20 \\
Sugar beet & 305 & 9333 & 3 & 0.13 \\
Dry farming & & & & \\
Barley & 80 & 250 & 1 & \\
\hline
\end{tabular}

\section{Tractor inventory of the enterprises}

Total number of tractors of black carrot-producing enterprises was 104 , thus the number of tractors per enterprise was 2.81. Number of tractors varied between 1-7 and $27 \%$ of enterprises had 1-3 tractors, $18.95 \%$ had 4 tractors, $16.2 \%$ had 2 tractors and $5.4 \%$ had $5-7$ tractors.

Distribution of tractor model years are presented in Figure 1. Of available tractors, $12.5 \%$ was 2013 model, $10.6 \%$ was 2016 model, $8.7 \%$ was 2014 and 2015 model, $6.7 \%$ was 2017 model, $5.8 \%$ was 2012 model,
4.8\% was 1998 and 2011 model and $3.8 \%$ was 2018 model. Tractor models varied between 1969 - 2018 and average tractor model was 2007. In other words, average age of tractors was 12 years. The ratio of 10 -years old tractors was $66.5 \%$. In Turkey, there were 1254 190 rubber-tired two-axial tractors with different power groups in 2018 and average tractor age was over 25 years (TUIK 2019; Anonymous 2019). Average tractor age in present study was lower than the country average.

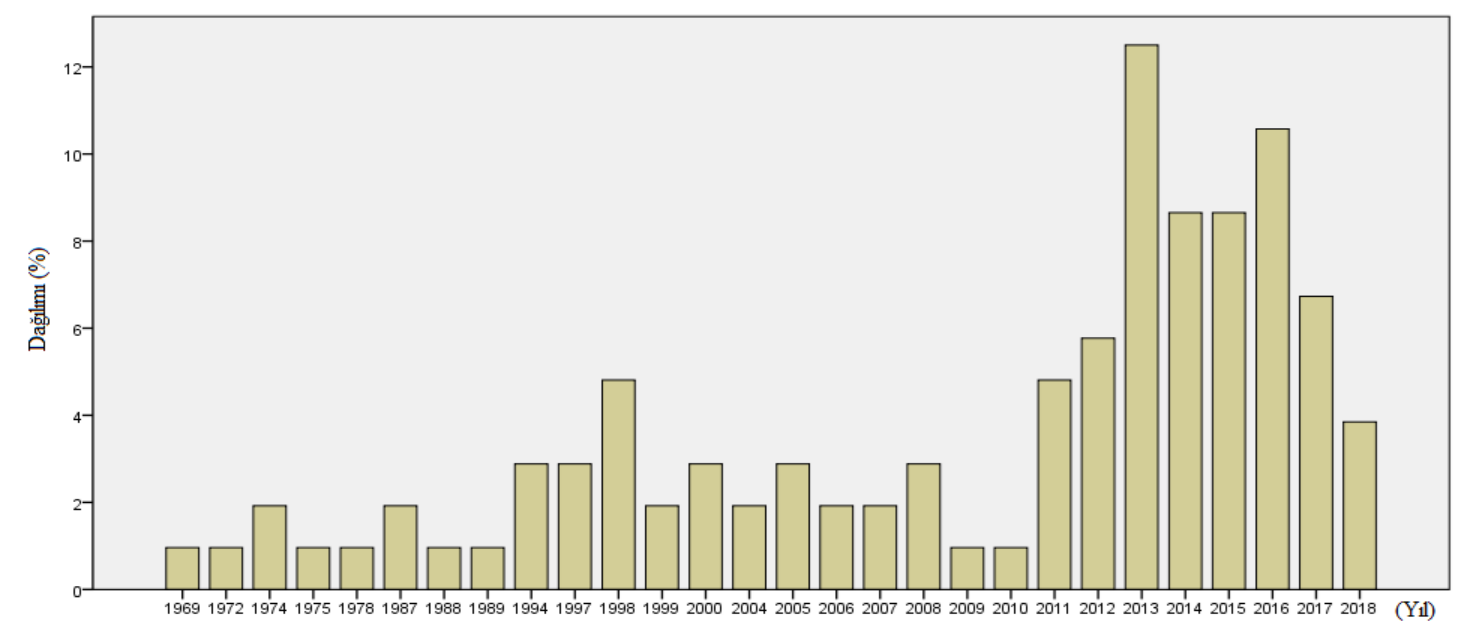

Figure 1

Distribution of tractor models

In Turkey, about 30 companies are in tractor market with about 40 brands. Therefore, there different brands of different companies in tractor parks of the enterprises. Of these tractors, $29.8 \%$ was New Holland, 24\% was Massey Ferguson, 18.3\% Tümosan, 16.3\% Fiat, $2.9 \%$ John Deere, $1.9 \%$ Ford, Erkunt and Hattat and about $1 \%$ was Kubato, Deutz and Claas Arion (Figure 2).

Average tractor power was $68.63 \mathrm{~kW}$. Average tractor power of Turkey is $44.2 \mathrm{~kW}$ (60 BG) (Anony- mous, 2019). Power distribution of present tractors is provided in Table 2. About $63.46 \%$ of tractors had a power of between 40.1 - $70 \mathrm{~kW}$. Evcim et al (2015) reported that $10 \%$ of Turkish tractor park had a power of greater than $51.5 \mathrm{~kW}$. In present study, $76.92 \%$ of tractors had a power of greater than $50.1 \mathrm{~kW}$. Present tractor powers and power distribution values were quite greater than the average of Turkey 


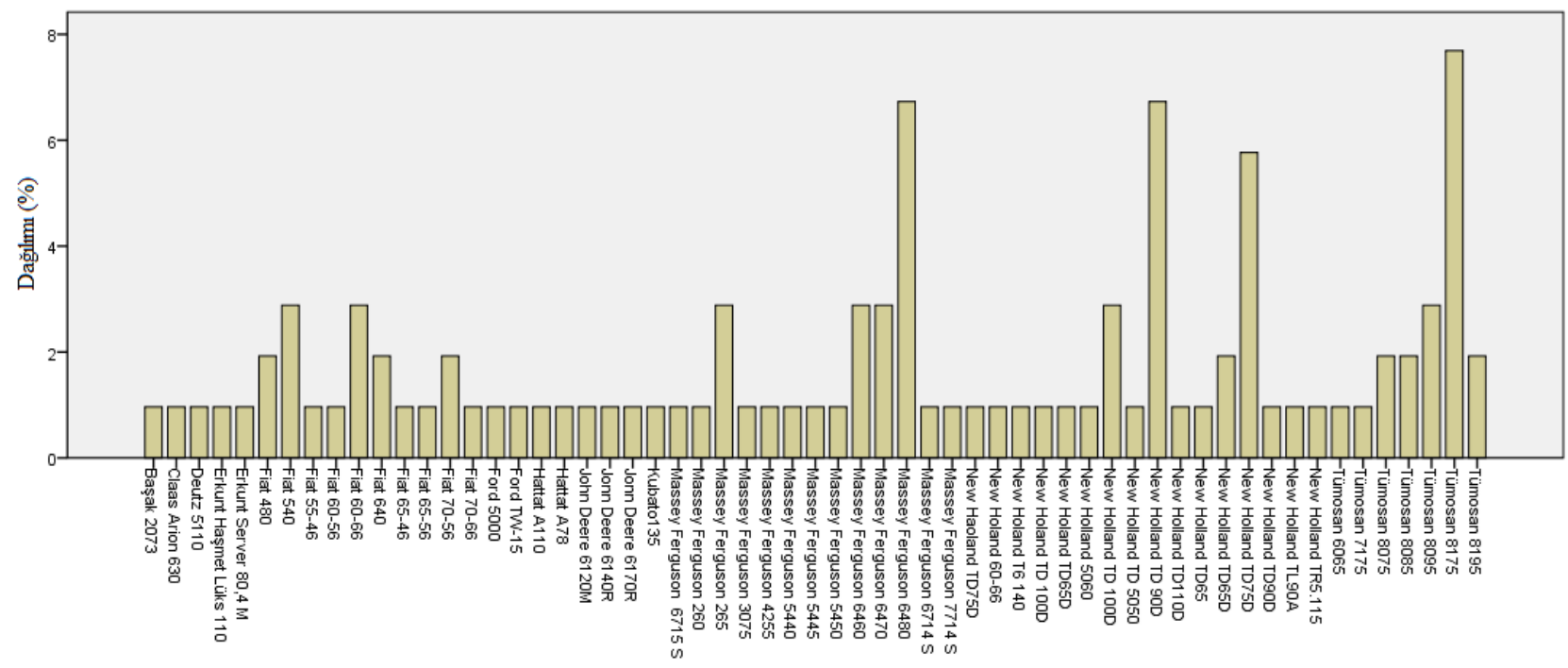

Figure 2

Distribution of tractor brands

Table 2

Power distribution of tractors of the enterprises

\begin{tabular}{lccc}
\hline Power $(\mathrm{kW})$ & Number of tractors & Percentage $(\%)$ & Average power of the groups $(\mathrm{kW})$ \\
\hline $35-40$ & 4 & 3.85 & 35.29 \\
$40.1-50$ & 20 & 19.23 & 45.73 \\
$50.1-60$ & 26 & 25.00 & 55.29 \\
$60.1-70$ & 20 & 19.23 & 65.93 \\
$70.1-80$ & 7 & 6.73 & 75.20 \\
$80.1-90$ & 9 & 8.65 & 84.56 \\
$90.1-100$ & 2 & 1.92 & 97.44 \\
$100.1-110$ & 6 & 5.77 & 105.52 \\
$110.1-120$ & 5 & 4.81 & 113.2 \\
$121.1-130$ & 5 & 4.81 & 122.8 \\
\hline Total & 104 & 100 & - \\
\hline
\end{tabular}

\section{Annual operational duration of tractors}

Annual fuel consumptions of the enterprises were determined. Among the annual fuel consumptions, fuel consumed by the diesel vehicles and trucks were not able to be clearly identified. Therefore, 12 enterprises with a truck were not taken into consideration and fuel consumptions of 55 tractors of only 25 enterprises were taken into consideration. Annual operational durations of the tractors varied between 147.7 - $1189.9 \mathrm{~h}$ with an average value of $657.2 \mathrm{~h}$ year $^{-1}$. Annual operational duration of tractors in Çumra town was reported as $532.5 \mathrm{~h}$ year $^{-1}$ (Keleş and Hacıseferoğulları 2016). High operational hours of black carrot-producing enterprises were attributed to large land size of the enterprises and contracting services for harvest-like mechanization practices.

\section{Agricultural machinery inventory}

Number of agricultural machines, common types, number of machines per tractor and enterprise are provided in Table 3.

There was a total of 678 agricultural tool - machine in present enterprises. Number of tool-machines per tractor was calculated as 6.52 and number of toolmachines per enterprise was calculated as 18.32 .

Distribution of the most common agricultural tool and machines of the enterprises were as follows: 116 trailer, 68 moldboard plough, 42 centrifuge-type fertilizer distributor, 43 vertical and horizontal-shaft rototiller, 40 pulverizator, 32 hoeing machine without fertilizer, 32 hoeing machine with fertilizer, 29 horizontal weeding machine, 25 silage machine and 22 cultivator. Number of these machines per enterprise was respectively calculated as $3.14,1.84,1.08,1.14,0.86,0.72$, $0.78,0.68$ and 0.59 . The other tools and machines followed these previous ones.

The black carrot-producing enterprises of Ereğli and Karapınar towns also produce cereals, feed crops and tomato. Moldboard plough and conventional soil tillage are commonly used in production of these commodities. Such a case can clearly be inferred from the number of moldboard ploughs in machine parks. Conventional soil tillage in black carrot production requires intensive tillage and thus generates soil compaction. 
Just based on production chain of black carrot, among the conservation soil tillage machines, there were 47 rototillers ( 25 horizontal-shaft and 18 verticalshaft) and they were used in seedbed preparations. Of the moldboard ploughs, $10.3 \%$ ( 7 ploughs) were rotarytype and 4 of them had 4 bodies and two of them had 2 bodies. Sandy soil texture of the region generally generates soil compaction problems.

Sowing was performed with pneumatic precise vegetable sowing machines in almost half (46\%) of the enterprises. About $70 \%$ of precise sowing machines were local brands and the other vegetable sowing ma-

\section{Table 3}

Number of agricultural machines, common types and number of machines per tractor and enterprise

\begin{tabular}{|c|c|c|c|c|c|c|c|c|}
\hline Agricultural machines & Number & Type / capacity & Range & Common type & $\begin{array}{l}\text { Common type } \\
\text { ratio } \\
(\%)\end{array}$ & $\begin{array}{l}\text { Machine/ } \\
\text { tractor }\end{array}$ & $\begin{array}{l}\text { Machine } \\
\text { enterprise }\end{array}$ & $\begin{array}{l}\text { Гotal mass } \\
\quad(\mathrm{kg})\end{array}$ \\
\hline Moldboard plough & 68 & Body & $3-6$ & 4 bodies & 60.65 & 0.65 & 1.84 & 41606 \\
\hline Subsoiler + chisel blaster & 14 & Leg & $5-13$ & 9 legs & 28.57 & 0.13 & 0.38 & 12567 \\
\hline Cultivator & 22 & Leg & $9-17$ legs & 13 legs & 40.90 & 0.21 & 0.59 & 21860 \\
\hline Horizontal shaft rototiller & 25 & Blade & 54 - 84 blades & 72 blades & 48.00 & 0.24 & 0.68 & 30055 \\
\hline Vertical shaft rototiller & 18 & Blade & 16 - 32 blades & 24 blades & 55.56 & 0.17 & 0.49 & 28435 \\
\hline Ridge making machine & 23 & Unit & 4 units & 4 units & 100 & 0.22 & 0.62 & 27600 \\
\hline $\begin{array}{l}\text { Hoeing machine with } \\
\text { fertilizer }\end{array}$ & 29 & Unit & $5-7$ units & 5 units & 65.51 & 0.28 & 0.78 & 25260 \\
\hline $\begin{array}{l}\text { Hoeing machine without } \\
\text { fertilizer }\end{array}$ & 32 & Leg & 4 & 4 & 100 & 0.31 & 0.86 & 8000 \\
\hline Trailer & 116 & Capacity & $3-10$ tons & 8 tons & 68.10 & 1.11 & 3.14 & $\begin{array}{l}290 \\
605\end{array}$ \\
\hline $\begin{array}{l}\text { Pneumatic vegetable } \\
\text { planting machine }\end{array}$ & 17 & Row & 4 rows & I rows - mechanical & 100 & 0.16 & 0.46 & 8925 \\
\hline $\begin{array}{l}\text { Centrifuge-type fertilizer } \\
\text { distributor }\end{array}$ & 40 & Tank capacity & $250-1000 \mathrm{~L}$ & $1000 \mathrm{~L}$ & 42.5 & 0.38 & 1.08 & 8043 \\
\hline Pulverizator & 42 & Tank capacity & $600-2000 \mathrm{~L}$ & $1000 \mathrm{~L}$ & 57.14 & 0.40 & 1.14 & 12840 \\
\hline Silage machine & 25 & $\begin{array}{l}\text { Number of } \\
\text { blades }\end{array}$ & 21 & 21 & 100 & 0.24 & 0.68 & 12500 \\
\hline Hay rake & 21 & Unit & $3-8$ & 5 & 42.85 & 0.20 & 0.57 & 4180 \\
\hline Horizontal straw chopper & 29 & $\begin{array}{l}\text { Number of } \\
\text { blades }\end{array}$ & 24 & 24 & 100 & 0.28 & 0.78 & 32480 \\
\hline $\begin{array}{l}\text { Suspended-type carrot } \\
\text { harvester }\end{array}$ & 18 & Two-row & 2 rows & 2 rows & 100 & 0.17 & 0.49 & 12420 \\
\hline Pull-type carrot harvester & 19 & Number of rows & $1-2$ & 2 & 57.90 & 0.18 & 0.51 & $\begin{array}{l}142 \\
800\end{array}$ \\
\hline Self-propelled carrot harvester & 4 & Two-row & 2 rows & 2 rows & 100 & 0.04 & 0.11 & 77000 \\
\hline Combined cereal harvester & 15 & Row & $16-32$ & 20 rows & 33.33 & 0.14 & 0.41 & 20701 \\
\hline $\begin{array}{l}\text { Mechanical carrot planting } \\
\text { machine }\end{array}$ & 1 & Row & 4 rows triple & 4 & 100 & 0.01 & 0.03 & 500 \\
\hline Maize silage machine & 7 & Row & $1-2$ rows & 1 row & 85.71 & 0.06 & 0.19 & 4850 \\
\hline Roller & 4 & $\begin{array}{l}\text { Operational } \\
\text { width }(\mathrm{m})\end{array}$ & $2.5-3.5$ & $3 \mathrm{~m}$ & 50.00 & 0.04 & 0.11 & 455 \\
\hline $\begin{array}{l}\text { Pneumatic precise sowing } \\
\text { machine }\end{array}$ & 8 & Unit (fertilizer) & $4-6$ & 4 units & 62.50 & 0.08 & 0.22 & 7475 \\
\hline Feed mixer and distributor & 12 & Tank capacity & $6-12 \mathrm{~m}^{3}$ & $8 \mathrm{~m}^{3}$ & 41.67 & 0.12 & 0.32 & 37750 \\
\hline Rotary drum mower & 8 & $\begin{array}{l}\text { Operational } \\
\text { width }\end{array}$ & $1.35-1.90$ & 1.65 & 62.5 & 0.08 & 0.22 & 3465 \\
\hline Disk mower & 3 & Number of disks & 6 disks & 6 disks & 100 & 0.03 & 0.08 & 2400 \\
\hline Double serrate blade mower & 5 & $\begin{array}{l}\text { Number of } \\
\text { blades }\end{array}$ & 22 & 22 & 100 & 0.05 & 0.14 & 900 \\
\hline Baler & 8 & $\begin{array}{l}\text { Rectangular and } \\
\text { roll }\end{array}$ & $\begin{array}{l}\text { Rectangular } \\
\text { and roll }\end{array}$ & Rectangular & 87.50 & 0.08 & 0.22 & 20580 \\
\hline Front loader & 15 & Tank capacity & $0.58-0.72 \mathrm{~m}^{3}$ & $0.72 \mathrm{~m}^{3}$ & 66.67 & 0.14 & 0.41 & 5560 \\
\hline Rear loader & 5 & Number of lifts & $1-2$ & $\begin{array}{l}\text { Double lift } \\
\left(0.28 \mathrm{~m}^{3}\right)\end{array}$ & 80.0 & 0.05 & 0.14 & 1800 \\
\hline Leveling blade & 21 & $\begin{array}{l}\text { Operational } \\
\text { width }\end{array}$ & $2-3 \mathrm{~m}$ & $2.4 \mathrm{~m}$ & 52.38 & 0.20 & 0.57 & 5770 \\
\hline Solid fertilizer distributor & 4 & Capacity & $6.5-15 \mathrm{~m}^{3}$ & $10 \mathrm{~m}^{3}$ & 50.00 & 0.04 & 0.11 & 19335 \\
\hline Fixed milking facility* & 14 & Number of heads & $7-20$ & 10 heads & 42.86 & - & - & - \\
\hline Truck* & 23 & Capacity & $20-30$ tons & 20 tons & 69.56 & - & - & - \\
\hline Beko loader* & 4 & $\begin{array}{l}\text { Front loader and } \\
\text { scraper }\end{array}$ & - & - & - & - & -- & \\
\hline Total & 678 & & & & & & & 982717 \\
\hline
\end{tabular}


In black carrot harvest, $10.8 \%$ of the enterprises were using self-propelled harvesters, $51.4 \%$ were using pull-type harvesters and $48.6 \%$ were using suspendedtype harvesters. All of the self-propelled harvesters and $94.7 \%$ of pull-type harvesters were imported. Suspended-type harvesters were local brands and some enterprises commonly use them for pull-out and boxing of black carrots.

Trailers are commonly used to transport pulled out black carrots to washing facilities. Therefore, number of trailers per tractor (1.11 trailers) and enterprise (3.14 trailers) had the greatest ratios.

Table 4

Agricultural mechanization level of black carrot-producing enterprises

\begin{tabular}{ll}
\hline Mechanization criteria & Value \\
\hline Number of enterprises & 37 \\
Cultivated land (ha) & 4161 \\
Number of tractors & 104 \\
Number of tractors per enterprise & 2.81 \\
Number of tool-machines per enterprise & $18.32 *$ \\
Average tractor power (kW) & 68.63 \\
Power per enterprise (kW enterprise $\left.{ }^{-1}\right)$ & 192.89 \\
Number of machines per tractor & $6.52^{*}$ \\
Cultivated land per tractor (ha tractor $\left.{ }^{-1}\right)$ & 40.01 \\
Machine mass per tractor (ton tractor $\left.{ }^{-1}\right)$ & 9.45 \\
Tractor power per unit of cultivated land $\left(\mathrm{kW} \mathrm{ha}^{-1}\right)$ & 1.72 \\
Number of tractors per 1000 ha of cultivated land $\left[\left(\right.\right.$ tractor $\left.(1000 \mathrm{ha})^{-1}\right]$ & 24.99 \\
\hline
\end{tabular}

It was reported in previous studies for Kadınhanı and Çumra towns of Konya province, number of tractors per enterprise was respectively 0.81 and 1.0 , number of tool-machines per tractor was 11.50 and 14.92, tractor power per enterprise was 39.92 and $60.89 \mathrm{~kW}$, average tractor power was 49.06 and $58.70 \mathrm{~kW}$, machine mass per tractor was 6.43 and 10.77 tons, average engine power per unit area was 1.91 and $4.08 \mathrm{~kW}$ ha $^{-1}$, number of tractors per 1000 ha cultivated land was 38.91 and 69.47 and cultivated land per tractor was 25.69 and 14.39 ha (Yalmanc1 2008; Keleş and Hacıseferoğulları 2016). It was reported in another study conducted with sunflower-producing enterprises of Çorum province that average tractor power of enterprises was $44.78 \mathrm{~kW}$, number of tool-machines per tractor was 5.2, average power per unit area was 3.99 $\mathrm{kW} \mathrm{ha}^{-1}$ and cultivated land per tractor was 10.78 ha (Bal and Altuntaş 2018). The present tractor power per unit of cultivated land and number of tractors per 1000 ha cultivated land were greater and the other parameters were lower than those earlier ones. Lower values were attributed to recently performed land consolidation in Akören village, thus intensive production and greater land size of enterprises (112.5 ha enterprise ${ }^{-1}$ ).

For Turkey in general, number of tractors per 1000 ha cultivated land is 45 , cultivated land per tractor is 26 ha, tractor power per unit area is $1.68 \mathrm{~kW} \mathrm{ha}^{-1}$, number of tool-machines per tractor is 5.2, machine mass per tractor is 4.2 tons and average tractor power is $44.2 \mathrm{~kW}$ (60 BG) (Anonymous, 2019). As compared to these values, present number of tractors per 1000 ha was

\section{Indicators of agricultural mechanization levels}

Indicators of mechanization levels for black carrotproducing enterprises are provided in Table 4 . Number of tractors per enterprise was 2.81, number of toolmachines per enterprise was 18.32, average tractor power was $68.63 \mathrm{~kW}$, tractor power per enterprise was $192.89 \mathrm{~kW}$, number of machines per tractor was 6.52 , cultivated land per tractor was 40.01 ha tractor $^{-1}$, machine mass per tractor was 9.45 tons, tractor power per unit of cultivated land was $1.72 \mathrm{~kW} \mathrm{ha}^{-1}$ and number of tractors per 1000 ha cultivated land was 24.99 . lower and the other parameters were greater than country averages.

\section{Conclusion}

The present study was conducted to determine agricultural mechanization characteristics of black carrotproducing agricultural enterprises. A database was generated with the aid of present data for mechanization planning of enterprises. Present parameters should be updated regularly to provide contributions to enterprise economies. For mechanization planning, some other variables such as climate data, time factors, energy needs of agricultural machines should be added to present database. In this way, optimum capacity tractors and machines suitable for enterprise sizes should be supplied to enterprises.

Land size of present enterprises were remarkable (112.5 ha enterprise-1). Over the black carrotproducing lands, land consolidation was performed only in Akören village. Land consolidation hasn't been performed in the other three villages. Therefore, number of plots varied between $1-32$ with an average value of 10.2. Total number of plots was 379 and average plot size was $78.8 \mathrm{da}$. Such a case makes the purchase of expensive agricultural machines difficult and also limits the size of agricultural tools and machines. Such small plots increase agricultural inputs and unit costs. Therefore, land consolidation works should be accelerated in the region. 
Average age of available tractors was 11 years. Such a value is lower than county (Turkey) average ( 25 years). It should be pointed out that data on tractor park and mechanization indicators were generally greater than country averages.

Further research is recommended about the average ages and economic lives of agricultural machines. Machines should be so selected as to comply with the tractor powers. Ratio of imported sowing and harvest machines is also remarkable. Such ratios should be reduced through manufacture and purchase of local brands. Number of different tool and machines for tomato, feed crops and cereals was sufficient in number and diversity.

\section{References}

Akar M, Çelik A (2017). Muş Ovası Tarım İşletmelerinin Tarımsal Mekanizasyon Özellikleri. Türk Tarım ve Doğa Bilimleri Dergisi, 4 (4), 491- 498.

Altuntaş E, Bal M (2018). Çorum İlinin Ayçiçeği Tarımı Yapan İşletmelerinin Mekanizasyon Düzeyinin Belirlenmesi. Selçuk Tarım ve Gida Bilimleri Dergisi, 32 (3), 381-393.

Anonim (2019). Türkiye Tarım Makinaları Sektörü Sektör Raporu. Derleyen Selami İleri.

Aslantürk B, Altuntaş E (2018). Malatya İlinin Tarımsal Mekanizasyon Düzeyi. Gaziosmanpaşa Bilimsel Araştırma Dergisi, 7 (2), 15-26.

Bozkurt M, Aybek A (2016). Şanlıurfa İli Harran Ovasının tarımsal yapı ve mekanizasyon özellikleri. Kahramanmaraş Sütçü Imam Üniversitesi Doğa Bilimleri Dergisi, 19 (3), 319-331.

Bridle P, Timberlake CF (1997). Anthocyanins as natural food colours-selected aspects. Food Chemistry, 58 (1), 103-109.

Canbaş A, Deryaoğlu A (1993). Şalgam suyunun üretim tekniği ve bileşimi üzerine bir araştırma. Doğa, 17, 119-129.

Evcim Ü, Tekin AB, Gülsoylu E, Demir V, Yürdem H, Güler H, Bilgen H, Alayunt F, Evrenosoğlu M (2015). Tarimsal Mekanİzasyon Durumu, Sorunlari ve Çözüm Önerİler. Türkiye Ziraat Mühendisliği VIII. Teknik Kongresi, Ankara, 1080-1106.
Giusti MM, Wrolstad RE (2003). Acylated anthocyanins from edible sources and their applications in food systems, Biochemical Engineering Journal. 14 (3), 217-225.

Işık A, Atun İ (1998). Şanlıurfa-Harran Ovasında Tarımsal Yap1 ve Mekanizasyon Özellikleri. Tr. J. of Agriculture and Forestry, 22, 151-160.

Kayhan İE, Aydın B, Baran MF (2017). Kırklareli İli Tarım İşletmelerinin Tarımsal Yapısı ve Mekanizasyon Düzeyi. Türk Tarım ve Doğa Bilimleri Dergisi, 4 (3), 263-270.

Keleş İ ve Hacıseferoğulları H (2016). Konya İli Çumra İlçesi Tarım İşletmelerinin Tarımsal Yapı ve Mekanizasyon Özelliklerinin Belirlenmesi, Selçuk Tarım Bilimleri Dergisi. 3 (1), 48-58.

Kipritçi DA, Bayhan AK, Baran MF (2018). Karaman İlinde Dane Mısır Üreten İşletmelerin Tarımsal Mekanizasyon Düzeyinin Belirlenmesi, Tarım Makinaları Bilimi Dergisi. 14 (1), 57-65.

Kırca A (2004). Siyah havuç antosiyaninlerinin bazı meyve ürünlerinde 1sıl stabilitesi. Doktora Tezi, Ankara Üniversitesi Fen Bilimleri Enstitüsü Gıda Mühendisliği Anabilim Dalı, Ankara.

Kirca A, Özkan M, Cemeroglu B (2006). Stability of black carrot anthocyanins in various fruit juices and nectars. Food Chemistry, 97 (4), 598-605.

Miişoğlu D (2004). Şalgam suyu üretiminde enzim uygulamasının verim ve kaliteye etkisi, Yüksek Lisans Tezi, Harran Üniversitesi Fen Bilimleri Enstitüsü Gıda Mühendisliği Anabilim Dalı, Şanlıurfa.

TUİK (2019). Türkiye İstatistik Kurumu verileri [Erişim tarihi: 25.06.2019]

Yalmancı B (2008). Konya ili kadınhanı ilçesinde tarım işletmelerinin tarımsal mekanizasyon düzeyinin belirlenmesi. Yüksek Lisans Tezi, Gaziosmanpaşa Üniversitesi Fen Bilimleri Enstitüsü Tarım Makinaları Anabilim Dalı, Tokat.

Yokuş S, Çarkacı A, Ölmez O, Karadavut U, Aydın C (2015). Konya'da Havuç Tarımı Yapan İşletmelerin Tarımsal Mekanizasyon Özellikleri. 29. Tarımsal Mekanizasyon ve Enerji Kongresi Diyarbakır, 5462. 